DOI: https://doi.org/10.18371/fp.3(43).2021.677680

УДК 004 [657] 658.849

\title{
ПОБУДОВА СИСТЕМИ АНАЛІТИКИ СУБ'ЄКТІВ ЕЛЕКТРОННОГО БІЗНЕСУ НА ОСНОВІ ВИКОРИСТАННЯ ХМАРНИХ ТЕХНОЛОГІЙ
}

\author{
ЛАКІЗА Вікторія Володимирівна \\ к.е.н., доиент кафедри менеджменту \\ і міжнародного підприємництва, \\ Інститут економіки і менеджменту \\ Національного університету «Львівська політехніка» \\ ORCID ID: https://orcid.org/0000-0002-6764-8536
}

Анотація. Висвітлено питання актуальності використання цифрових технологій. Наведено порівняння підходів до визначення категорій «хмарні технології», «обліковоаналітичне-забезпечення». Виділено типи хмарних послуг, систематизовано вимоги до аналітичної інформації, запропоновано перелік завдань для обліково-аналітичних систем суб'єктів електронного бізнесу, альтернативи використання ними хмарних технологій.

Ключові слова: хмарні технології, система аналітики, електронна комериія, суб'єкти електронного бізнесу.

Постановка проблеми. В сучасних умовах глобалізації економіки, а також тотального переходу суб'єктів бізнесу до європейських та світових стандартів надзвичайної значущості набуває застосування інформаційних комп'ютерних технологій, на основі чого виникає можливість підвищення результативності їх функціонування за умов лібералізації економічного простору. 3 практики господарювання підприємств можна стверджувати, що їх
Аннотация. Освещены вопросы актуальности использования циирровых технологий. Приведено сравнение подходов определения категорий «облачные технологии», «учетноаналитическое-обеспечение». Выделено типь облачных услуг, систематизировано требования к аналитической информации, предложено перечень задач и альтернатив использования облачных технологий учетноаналитическими системами субъектов электронного бизнеса.

Ключевые слова: облачные технологии, система аналитики, электронная коммерция, субъекты электронного бизнеса.

інформаційні системи дають позитивний ефект лише при якісній інтеграції 3 новітніми Інтернет-технологіями, зокрема розробці революційних технологічних рішень надзвичайно сприяє використання хмарних технологій. Їх застосування у всіх сферах традиційного та електронного бізнесу набуває все більшої актуальності, оскільки дозволяє суб'єктам підприємництва бути адаптивними та гнучкими, оптимізовувати при цьому витрати та уни- 
кати проблем перевиробництва в періоди економічного спаду та дефіциту під час активізації ділової активності.

Аналіз останніх досліджень і публікацій. Вивченням питань використання хмарних технологій суб'єктами бізнесу опікуються як закордонні так i вітчизняні науковці та практики бізнесу, проте вони досліджують дану проблематику здебільшого $з$ технічної точки зору.

Зокрема, М. А. Александрова зазначає, що «хмарні технології - це галузь обчислювальних технологій, у якій закладено принцип віддаленого доступу до обладнання і програм, що на ньому встановлені» [1].

У свою чергу О. І. Волот стверджує, що хмарні технології - це «технологія розподіленої обробки даних, в якій комп'ютерні ресурси і потужності надаються користувачеві як бізнессервіс» [2].

Хмарні технології - це технології розподіленої обробки цифрових даних, за допомогою яких комп'ютерні ресурси надаються інтернеткористувачеві як онлайн-сервіс [3]. 3і всього вищенаведеного можна зробити висновок, що сутність терміну $\epsilon$ простою: користувачі комп'ютерів не придбавають дороге вартісне устаткування та програмне забезпечення, а беруть його у оренду, оплачуючи при цьому тільки за термін його реального використання. Програмне забезпечення та обчислювальні потужності знаходяться на окремому видаленому сервері, в «хмарах».

Деяки автори також розглядають можливість використання хмарних технологій в системі аналітики суб'єктів бізнесу.

С.Я. Королем і А. Клочко охарактеризовано перспективи використання цифрових технологій у сфері бухгалтерського обліку, здійснено детальний аналіз видів цифрових технологій, які застосовуються в сфері бухгалтерського обліку та аудиту, а також наведено приклади їх впровадження [4]. Авторами зазначено, що «хмарні технології - це технології зберігання і роботи 3 даними онлайн в хмарі, а не на жорсткому диску комп’ютера або ноутбука».

А.М. Гафіяком [5] досліджено проблеми бізнесової аналітики та ії взаємозв'язку з сучасними IT- технологіям, а також взаємозв'язок інформаційних технологій та бізнесового аналізу. Доведено, що хмари значно скорочують витрати, в хмарах можна в найкоротші терміни розгорнути ITінфраструктуру чи окремі рішення, взявши у оренду необхідні ресурси й не переплачуючи при цьому на перспективу.

Значний внесок у дослідження та розробку додатків, що носять прикладний характер у галузі хмарних обчислень здійснено міжнародними IT- гігантами, такими як Microsoft, Google, Amazon.com, Intel, Dell, HP, Canonical, SUSE Linux та низкою інших. Проте на момент сьогодення потребують більш глибокого вивчення питання використання хмарних технологій в системі аналітики суб'єктів електронного бізнесу.

Метою статті $\epsilon$ вивчення системи аналітики суб'єктів електронного бізнесу на основі використання хмарних технологій. Об'єктом дослідження $\epsilon$ системи аналітики суб'єктів електронного бізнесу на основі використання хмарних технологій. Предметом дослідження $\epsilon$ оцінювання перспектив розвитку систем аналітики суб'єктів електронного бізнесу на основі вико- 
ристання хмарних технологій. Завданням статті являється дослідження перспектив застосування хмарних технологій у системах аналітики суб'єктів електронного бізнесу, визначення їх впливу на результати провадження електронного бізнесу тощо.

Виклад основних результатів дослідження. Бізнесова аналітика $є$ процесом трансформації даних у інформацію, тобто в нові знання, котрі можуть застосовуватись 3 метою нарощування результативності та конкурентоспроможності суб'єктів електронного бізнесу. Основою аналітичного забезпечення суб'єктів господарювання $\epsilon$ інформація - сукупність відомостей стосовно їх внутрішнього та зовнішнього середовищ, які використовують 3 метою оцінювання та аналізування економічних явищ і процесів, розроблення альтернативних варіантів та прийняття управлінських рішень.

Можемо стверджувати, що аналітична інформація повинна відповідати наступним вимогам [6]:

- чіткість i достовірність відображення в зовнішніх та внутрішніх формах звітності усіх господарських операцій, котрі здійснюються суб' єктами електронного бізнесу;

- подавання стейкхолдерам інформації стосовно поточного стану суб'єкта електронного підприє-мництва за допомогою розрахунку найважливіших якісних i кількісних фінансовогосподарських та техніко-економічних параметрів;

- виявлення, ідентифікування й відстеження розвитку внутрішніх і зовнішніх викликів, ризиків і загроз;

- протидія витоку конфіденційної інформації і промисловому Інтернет шпигунству;
- формування інформаційної бази задля прийняття альтернативних управлінських рішень у процесі управління діяльністю суб'єктів електронного бізнесу.

Отже, обліково-аналітична інформація $\epsilon$ результатом функціону-вання відповідної системи інформаційного забезпечення.

А. М. Штангрет пропонує обліковоаналітичне забезпечення управління суб'єктів господарювання розглядати як систему, так як воно, на думку автора «має ознаки, властиві системі: наявність зв'язків (у тому числі зворотних), поділ на частини, наявність структури (упорядкованих елементів), цілеспрямованість, збереження певної стійкості в заданих межах під впливом зовнішніх факторів та багатоаспектність» [6].

О. Гудзинський стверджує про те, що обліково-аналітична система $\epsilon$ iнтегрованою системою прийомів обліково-аналітичного забезпечення менеджменту за допомогою здійснення специфічних внутрішньо системних i загальносистемних функцій [7].

У свою чергу Г. Тітаренко й М. Корінько зазначають, що обліковоаналітична система представляє збирання, опрацювання й оцінювання всіх видів інформації, котрі використовується 3 метою прийняття управлінських рішень як на макро-, так і на макрорівнях [8].

На основі вищезазначеного можна зробити висновки, що обліковоаналітична система є системою, котра грунтується на даних оперативного, статистичного, фінансового та управлінського обліку, включає в себе оперативні дані, використовує для економічного аналізу статистичну, виробничу, довідкову й інші види інформа- 
ції за допомогою викорис-тання аналітичних та економіко-математичних методів дослідження, i це дозволяє формувати інформаційну базу для прийняття зважених та обгрунтованих управлінських рішень суб'єктами бізнесу.

При цьому до основних завдань обліково-аналітичних систем суб'єктів електронного бізнесу належать [9]:

- аналізування результатів їх діяльності за наперед визначеними напрямами;

- облікування господарських операцій за цільовими напрямами на основі бухгалтерського обліку із додаванням нефінансових показників;

- контролювання використання матеріальних і нематеріальних запасів, коректності відображення усіх господарських операцій на всіх етапах планування, об лікування, а також перманентний моніторинг достовір-ності аналітичних даних;

- планування діяльності суб'єкта підприємництва, його господарських операцій; видів діяльності (операційної, інвестиційної, фінансової);

- формування аналітичних бюджетів, як джерел акумулювання планової, облікової й аналітичної інформації на основі даних, отриманих від центрів відповідальності тощо.

Обліково-аналітичні

системи суб'єктів електронного бізнесу формуються на основі Business Intelligence (BI) - програмних засобів, які функціонують в рамках самих підприємств та забезпечують функції доступу й аналізування інформації, що міститься в сховищі даних, забезпечують прийняття обгрунто-ваних i коректних управлінських рішень.

Свого часу компаніями Gartner, Forrester, IDC було розроблено та за- пропоновано класифікації програмних засобів типу BI. Зокрема пропонована Gartner класифікація грунтується на тому, що програмні продукти кожного класу виконують певний набір операцій чи функцій із застосуванням спеціальних технологій. Компанією виділено наступні класи ВI: системи оперативної аналітичної обробки (OLAP); засоби побудови сховищ даних (data warehousing); засоби інтелектуального аналізу даних (data mining); інформаційно-аналітичні системи (Enterprise Information Systems, EIS); інструменти для виконання запитів та побудови звітів (query and reporting tools) [10].

Компанія Forrester пропонує розглядати програмні засоби типу Business Intelligence насамперед в розумінні «набору методологій, процесів, архітектури та технологій, що перетворюють вихідні дані в корисну та змістовну інформацію, котра використовується для прийняття рішень, ефективних щодо стратегіï, тактики та функціонування компанії» (традиційне визначення терміну «Business Intelligence»); на момент сьогодення активно використовується також і додаткове (вузьке) визначення терміну «Business Intelligence», щл передбачає врахування двох сегментів ВI - підготовка даних (data preparation) і використання даних (data usage) зокрема: «набору методологій, процесів, архітектури та технологій, що використовують результат процесу інформаційного менеджменту для аналізу, звітності, управління продуктивністю та доставки інформації» [10].

Компанія IDC, в свою чергу, програмні засоби типу ВI пропонує розглядати як засоби кінцевого користувача для звітності, запитів та аналізу (end-user query, reporting and analysis - 
QRA); розширену аналітику (advanced analytics software). До першої групи пропонується включити засоби формування та виконання запитів користувача й звітності, а також здійснення простого аналізу. Інструменти багатомірного аналізу включають і OLAPсервери, і клієнтські аналітичні інструменти, котрі забезпечують середовище управління даними 3 метою моделювання бізнес-проблем і аналізування бізнес-даних. Розширена аналітика при цьому включає в себе засоби вилучення даних (data mining) та статистичне програмне забезпечення (statistical software). Інструментальні засоби цієї категорії використовують вивід правил методом індукції, нейронні мережі, кластеризацію, виявлення зв'язків у даних, прогнозування схованих тенденцій (котрі неможливо розпізнати лише за рахунок OLAPзасобів) [10].

Сучасний електронний бізнес активно розвивається, задаючи при цьому нові бізнес-тенденції, на які потрібно орієнтуватися. Хмарні технології відіграють у цьому важливу роль, так як їх використання дозволяє встановлювати пріоритети, прискорювати процес прийняття важливих стратегічних рішень, поліпшувати переробку та отримання інформації, підвищувати продуктивність і операційну ефективності функціонування. Хмарні технології являються одним із прогресивних підходів стосовно автоматизації бухгалтерського обліку та оптимізації бізнес-процесів. Хмарні технології є технологіями зберігання та роботи 3 даними онлайн у хмарі, а не на жорсткому диску комп'ютера чи ноутбука. Саме доступ до програм через хмару незалежно від того, де знаходиться користувач та який пристрій він засто- совує, забезпечує вільний потік інформації. Хмара також дозволяє внутрішнім і зовнішнім користувачам отримати доступ до даних стосовно результатів діяльності суб'єкта підприємництва, полегшуючи при цьому спільну роботу та оптимізовуючи процес обміну інформацією.

Схематично всі види хмарних послуг поділимо на три типи:

- Platform as a Service (платформа як послуга) - набори готових компонентів для створення додатків, а також фреймворки для керування платформою (наприклад, Google AppEngine, Red Hat's OpenShift; VMWare Pivotal Cloud Foundry та ін.);

- Infrastructure as a Service (інфраструктура як послуга) - найбільш наближена до володіння власним «залізом» і віртуалізацією, клієнт отримує в своє розпорядження хмарні процесори, диски й мережі, пам'ять, із яких згодом створить серверимаршрутизатори й налаштує мережеву топологію так, як йому необхідно ;

- Software as a Service (програмне забезпечення як послуга) - передбачає надання клієнту готового рішення 3 мінімальною необхідністю налаштування(наприклад, Dropbox, Evernote, Trello).

Адаптувати $\mathrm{SaaS}$ точно під власні бізнес-потреби клієнту навряд чи вдасться, проте й здійснити побудову готового рішення на базі IaaS за декілька годин також майже неможливо. Також слід звернути увагу на потребу побудови мультивендорних рішень, а це в випадку iз SaaS та PaaS може бути дуже навіть складно. В Україні ж чим більшою $є$ компанія, тим більш різнорідною $є$ іiї інфраструктура, й тим частіше вона схиляється до використання хмарних IaaS послуг. Малий і середній 
бізнес здебільшого орієнтується на SaaS-рішення.

Про динамічність розвитку ринку хмарних технологій можна зробити висновок вже навіть по тому, що обсяг ринку хмарних сервісів лише класу IaaS в 2019 р. склав близько 29 млн. дол. США. Зростання порівняно 3 2018 р. становило 45\%. Проте 2020 р. для ринку хмарних сервісів як України, так і решти країн світу через вплив пандеміï Covid-19 був обвальний. Припускається, що обсяг продажів IT товарів та послуг в Україні в 2020 р скоротився, і схожа яма була лише в 2015 p. [13]. В цілому економічна турбулентність, а також нестабільність курсу гривні підсилюють позиції хмарних сервісів порівняно з традиційними CapEX-орієнтованими сегментами IT ринку. Власне тому одним із найсильніших стимулів стосовно розвитку та модернізації в Україні являється погіршення, загроза, криза. Слід звернути увагу га ой факт, що за умови економічних «гойдалок» із широкою амплітудою українські хмарні оператори збільшують власні частки ринку значно швидшими темпами, аніж їх закордонні колеги.

На основі досліджень, які здійснює консалтингова компанія Gartner, за останні роки спостерігається стрімкий розвиток індустрії хмарних рішень. Зокрема, за прогнозами компанії, сукупні світові витрати на публічні хмарні сервіси збільшаться на $23,1 \%$ у 2021 р. та становитимуть 332,3 млрд. дол. США порівняно 3270 млрд. дол. США в 2020 р. Витрати на хмарні IaaS послуги у 2021 р. становитимуть 82,02 млрд. дол. США та у 2022 р. збільшаться до 106,8 млрд. дол. США., продемонструвавши при цьому $24,7 \%$ прогнозний у 2022 р., порівняно із
2021 p. Також на основі прогнозів Gartner спостерігаємо перманентне зростання світових витрат кінцевих споживачів на публічні хмарні послуги з 242,6 млрд. дол. США в 2019 р. до 692,1 млрд. дол. США в 2025 р., і це становитиме $16,1 \%$ середньорічних темпів приросту [15].

На момент сьогодення сотні українських підприємств підтвердили їх поведінкою, що хмарна модель споживання IT сервісів є вигіднішою, ефективнішою і кращою не лише в період активного бізнес-зростання, але й за умов максимальної економічної нестабільності. Сектор невеликих споживачів хмарних сервісів, а 3 ними й усі оператори, котрі їх обслуговували, несуть найбільш відчутні втрати. Пандемічні кризові явища негативно впливають на діяльність маленьких та слабких гравцями.

Сьогодні «хмарний» світ контролюють інформаційні гіганти Microsoft Azure, De Novo, AWS, Gigacloud, Google Cloud Platform і латвійський ТЕТ. Ці компанії по всьому світові обіймають істотну частку ринку (окрім Китаю, в якому $\epsilon$ ще й Alibaba Cloud) та $є$ технологічними лідерами, що задають тренди у розвитку хмарних IaaS сервісів. Наступними йдуть дрібніші гравці світового ринку (наприклад OVH, iLand, GreenCloud), хоча кожен із них в цілому міг би заповнити власними виробничими потужностями український ринок. Здебільшого це є гравці, що орієнтуються на певний регіон або ж країну та не розповсюджені за межами власного ареалу.

Говорячи про українських локальних провайдерів, вітчизняні замовники отримують більшу вартість ресурсів, а також локальну угоду. Надзви- 
чайно важливим $\epsilon$ факт відсутності прив'язки до іноземної валюти. Окрім того, на вітчизняному ринку представлено декілька незалежних провайдеpiв, зокрема, компаніï «FreeAgent» (Великобританія), «Baltneta» (Литва), «GigaCloud» (Україна), «Netsuite» (США), «KashFlow» (США), «Intuit Quickbooks» (CШA), «Netsapiens» (СШA), «Sage 50c Premium» (США), «SAP Business One» (Німеччина), «Xero» (Нова Зеландія), «Wave» (Kaнада) та ін. Головною технологічною опорою ключових українських операторів є платформа від VMware - aмeриканського виробника хмарного прогрманого забезпечення світового класу.

На закордонних ринках пропонуються такі варіанти експлуатації хмарних технологій [4]:

- використання ресурсів ITінфраструктури провайдера на умовах оренди чи інфраструктури як послуги. При цьому клієнт використовує інфраструктуру 3 метою встановлення будь-якого програмного забезпечення та додатків (на основі низки різних технологічних платформ) i виконання бізнес-операцій. Провайдер надає й обслуговує сервери, мережеві компоненти та сховища даних;

- використання IT- інфраструктури та платформи (веб-сервер чи база даних) провайдера на умовах оренди у вигляді послуги чи платформи як послуги. При цьому клієнт здійснює управління програмними продуктами (додатками), а провайдер - самою операційною системою;

- використання програмного забезпечення провайдера на умовах оренди у вигляді послуги чи програмного забезпечення у вигляді послуги, коли клієнт користується додатком, а базо- вими налаштуваннями додатку керує сам провайдер.

Слід звернути увагу на те, що вітчизняний оператор GigaCloud пропонує переводити програмні продукти, що розроблені на платформі «1С», й відповідної бази даних на хмарний сервіс - у Інтернет із застосуванням програмного продукту «1С: Фреш» [12]. Такий перехід на подібні продукти не лише істотно полегшить роботу бухгалтера за рахунок автоматизування низки технічних процедур, надання цілодобової технічної підтримки, високої швидкості роботи й змоги працювати у програмі одночасно двом i більше працівникам, проте й сприятиме поширенню практики застосування хмарних технологій у обліку й інших сферах професійної діяльності.

Позитивні і негативні сторони застосування хмарних технологій в системах обліку суб'єктів підприємництва узагальнено подано в табл. 1 [2, 4 ].

Новітні IT-технології все активніше проникають в діяльність всіх суб'єктів бізнесу, причому тотальній автоматизації підлягають всі сфери їх діяльності, і це дозволяє їм у всіх напрямках переходити на новий рівень взаємодії. «Хмарні» технології дозволяють суб' єктам електронного бізнесу:

1) забезпечувати повсюдний доступ та належний рівень обчислювальних потужностей «за вимогою»;

2) значно простіше вирішувати проблеми нерівномірності потреб у обчислювальних потужностях під час пікового навантаження, або ж навпаки, затишшя;

3) оптимізувати та передбачати низку витрат за умови переміщення процесів на спеціалізовані сторонні «хмарні» хостинги та використання за потребою лише певних їх опцій, зокрема, й у 
сфері аналітики, а також приймати на основі цього більш виважені та обгрунтовані управлінські рішення, покращити систему документообігу та опе- раційну ефективність за допомогою інфраструктури, збільшити ефективність обслуговування клієнтів тощо.

Таблиця 1

Позитивні і негативні сторони застосування хмарних технологій

\begin{tabular}{|c|c|}
\hline Позитивні & Негативні сторони \\
\hline $\begin{array}{l}\text { сприяння переходу } 3 \text { «паперового» на електронний } \\
\text { варіант роботи й зберігання даних із застосуванням } \\
\text { сховищ даних }\end{array}$ & $\begin{array}{l}\text { відсутність чітких угод стосовно рівнів } \\
\text { обслуговування значно ускладнює } \\
\text { процес оцінювання клієнтами міри } \\
\text { безпеки й розробку власних заходів із } \\
\text { забезпечення виконання своїх стандар- } \\
\text { тів і стандартів контролюючих органі- } \\
\text { зацій }\end{array}$ \\
\hline $\begin{array}{l}\text { забезпечення безперервності діяльності на основі } \\
\text { здійснення регулярного автоматичного резервного } \\
\text { копіювання, зберігання в хмарі архівних копій баз } \\
\text { даних, їх швидкого відновлення після аварій тощо }\end{array}$ & $\begin{array}{l}\text { необхідність постійного підключення } \\
\text { до Інтернету, причому якісного та ба- } \\
\text { жано широкосмугового }\end{array}$ \\
\hline $\begin{array}{l}\text { мобільність застосування баз даних, котрі розміще- } \\
\text { ні на хмарі, в будь-якій точці світу, де існує Інтер- } \\
\text { нет та наявні відповідні технічні засоби }\end{array}$ & $\begin{array}{l}\text { зростання кількості підключень до } \\
\text { сервісів, що обумовлюе питання дос- } \\
\text { тупу та потребуе централізованого } \\
\text { процесу авторизації }\end{array}$ \\
\hline $\begin{array}{l}\text { оновлення програмних продуктів провайдерами } \\
\text { здійснюєтья автоматично без участі персоналу } \\
\text { компанії, що сприяє зменшенню потреби в обслу- } \\
\text { говуванні апаратного забезпечення та комунікацій- } \\
\text { них мереж }\end{array}$ & $\begin{array}{l}\text { недостатній рівень безпеки зберігання } \\
\text { та передачі даних, що випливає з архі- } \\
\text { тектури хмари даних. }\end{array}$ \\
\hline $\begin{array}{l}\text { масштабованість відповідно до зростання бізнесу } \\
\text { інфраструктури суб'єкта підприємництва }\end{array}$ & $\begin{array}{l}\text { складність відновлення втрачених } \\
\text { «хмарі» інфформаційних ресурсів }\end{array}$ \\
\hline $\begin{array}{l}\text { суттєве скорочення капітальних витрат користува- } \\
\text { чів інформаційних технологій, які перебирають на } \\
\text { себе провайдери }\end{array}$ & \\
\hline $\begin{array}{l}\text { Перманентне розширення спектру послуг, що про- } \\
\text { понуються виробниками і провайдерами хмарних } \\
\text { рішень, що зазвичай відповідає зростаючим мож- } \\
\text { ливостям сучасної комп’ютерної техніки }\end{array}$ & \\
\hline
\end{tabular}

Джерело: узагальнено автором на основі $[2,4]$

Висновки. Хмарні технології сьогодні $є$ одним із істотних факторів міжнародного розвитку, вплив котрого на глобальний ринок найближчим часом суттєво збільшиться. Застосування в практиці електронного бізнесу новітніх технологій відіграє надзвичайно важливу роль, оскільки їх чітке розуміння дасть можливість істотно підвищити надійність, якість праці всіх користувачів хмарних сервісів, оптимізувавши при цьому витрати на створення та підтримку самих сервісів, а також збільшивши ефективність функціонування суб'єктів бізнесу за умови зваженої політики використання їх ресурсів. 


\section{Список використаної літератури}

1. Александрова М. А. Використання хмарних технологій у бізнесі та побудова моделі переходу до них. Вісник Національного технічного університету "ХПІ": збірник наукових праць. Тематичний випуск: Актуальні проблеми управління та фінансово-господарської діяльності підприємства. 2014. № 66 (1108). C. 3-6.

2. Волот О. І. Застосування хмарних технологій в обліку та управлінні підприємствами реального сектору економіки. Центральноукрайнський науковий вісник. Економічні науки. 2019. №2(35). С. 190-198.

3. Що таке хмарні технології і навіщо вони потрібні. веб-сайт. URL: https://edin.ua/shho-take-xmarni-texnologi\%D1\%97-i-navishho-voni-potribni/ (дата звернення: 09.10.2021).

4. Король С.Я., Клочко А. Технології в обліку й аудиті. Держава та регіони. Серія: Економіка та підприємниџтво. 2020. № 1 (112). С.170-176.

5. Гафіяк А.М. ІТ-технології та бізнес-аналітика. Економіка і суспільство. 2018. № 15. С. 933-937.

6. Штангрет А. М. Обліково-аналітичне забезпечення управління економічною безпекою підприємства. Вісник асоціачії докторів філософії України. 2015. № 1. URL: http://aphd.ua/publication-31/ (дата звернення: 09.10.2021).

7. Гудзинський О. Д., Кірейцев Г. Г., Пахомова Т. М. Теоретичні аспекти формування обліково-аналітичного механізму менеджменту. Облік $і$ фінанси АПК. 2008. № 3. C. 89-93.

8. Тітаренко Г. Б., Корінько М. Д. Методичні підходи для побудови обліковоаналітичної системи з використанням експертних оцінок. Облік і фінанси АПК. 2010. № 4. С. 66-69.

9. Садовська І. Б. Обліково-інформаційне забезпечення управлінського аналізу. Вісник НУ «Львівська політехніка»: «Менеджмент та підприємництво в Украӥні: етапи становлення і проблеми розвитку». 2009. № 647. С. 498-503.

10. Карлберг К. Бизнес-анализ с использованием Excel. Решение бизнес-задач, 4-е издание Business Analysis: Microsoft Excel. Москва: «Вильямс», 2013. 576 с. 11. Хмарні технології підвищують ефективність роботи та допомагають зменшити витрати. URL: https://cloudfresh.com/ua/cloud-blog/hmarni-tehnologijpidvyshhuyut-efektyvnist-roboty-ta-dopomagayut-zmenshyty-vytraty/ (дата звер- 
нення: 10.10.2021).

12. Гаврилюк А. Яку 1C вибрати: в хмарі чи локальну? URL: https://golossokal.com.ua/cikavo/yaku-1s-vybraty-vkhmari-chy-lokal-nu.html (дата звернення: 11.10.2021).

13. Агєєв М. Ринок хмарних сервісів в Україні в 2020 році. URL: https://ua.interfax.com.ua/news/blog/708733.html.html (дата звернення: 10.10.2021).

14. Кобєлєв В. М., Кучма, В. Д. Використання хмарних технологій в маркетингу та електронній комерції. Вісник Національного технічного університету "ХПІІ. Серія: Економічні науки. 2017. № 24 (1246). С. 35-39

15. Gartner, 2021. URL: https://www.gartner.com/en/industries/high-tech (дата звернення: 12.10.2021). 